\title{
EFFECT OF FRICTION CONDITIONS ON CHANGE OF SHEET SURFACE ROUGHNESS DURING DEEP DRAWING
}

\begin{abstract}
The article deals with problems related to analysis of friction existed in sheet metal forming. In order to determine the influence of surface parameter value of the sheets, surface parameters of the rollers and pressure force on friction coefficient value the strip-drawing friction tests have been performed. Furthermore, the analysis of the effect of friction conditions on the change of sheet roughness parameters has been done. The topographical analysis of tested samples was carried out by using the measurement system Alicona InfiniteFocus. As the testing materials lowcarbon deep drawing quality steel sheet has been used. In case of rolls with surface roughness parameter value of $R a=0.63$ and $1.25 \mu \mathrm{m}$ the smoothing of peaks roughness during the friction process was observed. For the roll with surface roughness value of $R a=2.5 \mu \mathrm{m}$ the highest deviation of the surface after friction tests in respect of the reference surface exists below the reference surface. In all analyzed frictional conditions the decreasing of the value of the surface roughness parameters $S s k$ and $S k u$ characterizing the topography of the sheets was noticed. During tests realized in dry friction conditions the value of surface roughness parameter $S s k$ was smaller than for lubrication conditions. In case of $S k u$ parameter the reverse dependence was observed.
\end{abstract}

Keywords: coefficient of friction, friction, sheet metal forming

\section{Introduction}

During processes of sheet metal forming with the help of rigid tools a meaningful influence on frictional resistance have macro- and microgeometry of contact surfaces. Moreover, resistance to friction depends on physical and chemical factors acting on the contact surface, dynamics of load, temperature [1-4] and directionality of sheet surface topography [5]. In majority of sheet metal forming processes existence of frictional resistance is undesirable pheno-

\footnotetext{
${ }^{1}$ Anna Bazan, Rzeszow University of Technology, 2 W. Pola St., e-mail: abazan @ prz.edu.pl

2 Autor do korespondencji/corresponding author: Tomasz Trzepieciński, Rzeszow University of Technology, 8 Powstańców Warszawy Avenue, 35-959 Rzeszow, tel. (17) 8651714, e-mail: totrz@prz.edu.pl
} 
menon and case: strain non-uniformity especially in thin-walled drawpieces, increasing of forming forces, decreasing of tool life and quality of product conformance. A huge number of friction tests for simulation of friction conditions in different regions of formed drawpiece was developed and tested $[2,4,6]$.

During sheet metal forming initially there is only a local contact of peaks of roughness so a real area of the contact is slide. Under the influence of pressure force the peaks of roughness was deformed and came into existence contact surface is sufficient to load transfer. In the recent research $[7,8]$ it was found that dependence between the friction coefficient value and normal pressure is nonlinear. Microgeometry of the contact characterized by 2D and 3D roughness parameters has essential influence on nature of tribological phenomena in the contact zone and the friction force value. In the deep drawing process the strip drawing test simulating the friction phenomenon existed between a punch and a wall of the drawpiece. During the friction test a sheet strip was pulled between two rollers. The parameters influencing on change of frictional resistance during the strip drawing test are clamping force of the rollers, lubrication conditions, pulling speed and surface roughness of the rollers. The strip drawing friction test was proposed by Weinmann et al. [9], in such fixture the flow of metal around the punch corner was reproduced stretching a metal strip around two fixed rollers and monitoring and recording the strains in the wall portions and in the bottom portion of the specimens. Such data were utilized to calculate the corresponding tension values and from these the friction coefficients were determined. Many researchers have used the strip-drawing friction test and showed that friction strongly influences the formability in various regions of the formed drawpiece. An original multi-pass strip drawing test in cylinder/sheet/cylinder contact geometry is presented and we emphasize the influence of certain factors rarely taken into account in the experimental simulation. A small friction coefficient does not always lead to lower tribological loads [10]. Choudhury et al. [11] has observed that, with the increase of friction coefficient the blank holder force decreases. Costa and Hutchings [12] strip-drawing test were used to investigate the effect of surface texturing in tribological applications involving mixed lubrication and plastic deformation.

\section{Experimental procedure}

The friction tests were carried out using the strip drawing test using a special device [8] mounted in tensile machine. Samples were prepared as a strip having $20 \mathrm{~mm}$ width and about $200 \mathrm{~mm}$ length, cut along transverse direction of the sheet. The strip was clamped with specified force between two cylindrical rolls with a diameter of $20 \mathrm{~mm}$ made of cold-work tool steel NC6. The low-carbon deep drawing quality (DDQ) steel was selected as a testing material. Spatial surface roughness parameters (Table 1) were measured using the measurement system Alicona InfiniteFocus. The measured area is then $1.4301 \mathrm{x}$ 
$1.0849 \mathrm{~mm}^{2}$ with point size $438 \times 438 \mathrm{~nm}^{2}$ and a polynomial fit of the measured area.

Table 1. The surface roughness parameters of the tested sheets

\begin{tabular}{|c|c|c|c|c|c|c|c|}
\hline Material & $\begin{array}{c}\text { Arithmetical } \\
\text { mean height } \\
\text { of the sur- } \\
\text { face } \\
S a \\
{[\mu \mathrm{m}]}\end{array}$ & $\begin{array}{c}\text { Root } \\
\text { mean } \\
\text { square } \\
\text { height } \\
\text { of the } \\
\text { surface } \\
S q \\
{[\mu \mathrm{m}]} \\
\end{array}$ & $\begin{array}{c}\text { Root mean } \\
\text { square } \\
\text { gradient of } \\
\text { the surface } \\
S d q \\
{[\mu \mathrm{m} / \mu \mathrm{m}]}\end{array}$ & $\begin{array}{c}\text { Surface } \\
\text { bearing } \\
\text { index } \\
S b i\end{array}$ & $\begin{array}{l}\text { Valley } \\
\text { fluid } \\
\text { retention } \\
\text { index } \\
\quad S v i\end{array}$ & $\begin{array}{c}\text { Skewness } \\
\text { of surface } \\
\text { height } \\
\text { distribu- } \\
\text { tion } \\
\text { Ssk }\end{array}$ & $\begin{array}{c}\text { Kurtosis } \\
\text { of sur- } \\
\text { face } \\
\text { height } \\
\text { distribu- } \\
\text { tion } \\
\text { Sku }\end{array}$ \\
\hline DDQ & 1.79 & 2.21 & 0.133 & 0.246 & 0.109 & 0.0286 & 2.82 \\
\hline
\end{tabular}

Various tribological conditions were obtained by using rollers with different values of surface roughness parameters $R a$ defined as $R a^{w}: 0.63,1.25$ and 2.5 $\mu \mathrm{m}$. These parameters were measured along generating line of rollers. The topography of rollers has been shown in Fig. 1. Analysis of surface topography of tested sheets for different rollers allows observing visible directionality of geometrical structure of surface. Values of both forces, the clamping force $F_{C}$ and the pulling force $F_{P}$, were constantly recorded using electric resistance strain gauge technique, 8-channel universal amplifier of HBM's QuantumX data acquisition system and computer PC.

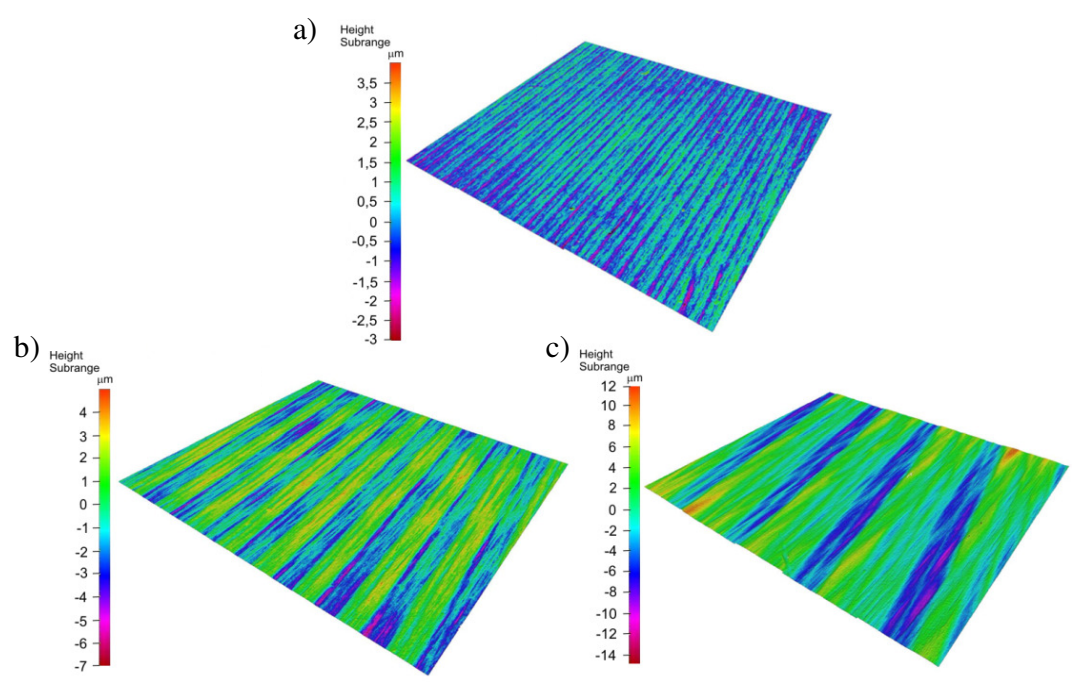

Fig. 1. Views of surface of rollers with value of $R a$ parameter equals: a) $0.63 \mu \mathrm{m}$, b) $1.25 \mu \mathrm{m}, \mathrm{c}$ ) and $2.5 \mu \mathrm{m}$; measured area: $3.2228 \times 2.816 \mathrm{~mm}$ 
The value of clamping force is changed simultaneously during the test in the range of $0.25 \div 2 \mathrm{kN}$. The range of clamping force variation was assumed based on the adequacy principle to real conditions of deep drawing. The Hertz's contact pressure during strip-drawing test may be determined by using following equation:

$$
p_{H}=\sqrt{\frac{0.418^{2} F_{C} E}{b R}}
$$

where: $F_{N}$ - clamping force of rollers, $F_{C}=0.25 \div 2 \mathrm{kN}$,

$E$ - Young's modulus of sheet material, for low-carbon steel it was assumed $E=205 \mathrm{GPa}$ [13],

$b$ - width of sheet strip, $b=20 \mathrm{~mm}$,

$R$ - roller diameter, $R=10 \mathrm{~mm}$.

In processes of sheet metal forming of drawpieces with complex geometry in different parts of formed element exists extremely various values of normal pressure which significantly change the contact conditions. Values of Hertz's contact pressure related to assumed range of clamping force value are equal about $210 \div 600 \mathrm{MPa}$. The maximum of contact pressure is related to contact pressure values existed during deep drawing [14]. To realize various friction conditions both rollers and specimens were degreased by using acetone for dry conditions, and for oil conditions the LAN-46 oil was used. The mean value of the friction coefficient is determined according to Eq. (2) for the stabilized range of values of $F_{P}$ and $F_{C}$ :

$$
\mu=\frac{F_{P}}{2 \cdot F_{C}}
$$

where: $F_{P}$ - pulling force,

$F_{C}$ - clamping force.

\section{Results and discussion}

The influence of different friction conditions on change of surface parameters value of tested sheets has been determined. The general relationship was the decrease of the friction coefficient value as the clamping force value increases for both dry and oil conditions (Fig. 2). It can be explained by the fact that after exceed a certain value of normal pressure the relationship between the friction force and pressure force is nonlinear. Consequently the friction coefficient value is not constant and changes as the pressure force increases. As the $R a$ parameter of rollers surface increases the coefficient of friction also increases for both analyzed friction conditions. The variation of value of friction coefficient determi- 
ned in dry friction conditions versus determined in oil conditions for all clamping forces has been shown in Fig. 3. For all applied clamping forces and all rollers the percentage of reduction of friction coefficient value in oil conditions is similar. It was found, that relationship between values of friction coefficient determined in dry and oil conditions is approximately linear. The coefficient of determination $R^{2}$ was equal about 0.93 .

Variation of contact conditions determines the variation of surface topography of the sample (Table 2). Topographical analysis of samples was carried out by using optical 3D surface measurement systems Alicona Infinite- Focus. Measurements of surface roughness were carried out for samples tested in dry and oil conditions for clamping force of $0.8 \mathrm{kN}$ and using all rollers. The measurements of functional parameters of surface microgeometry after strip drawing tests do not give unequivocal response how the change of friction conditions influences on variation of surface topography of sheets.

a)

b)
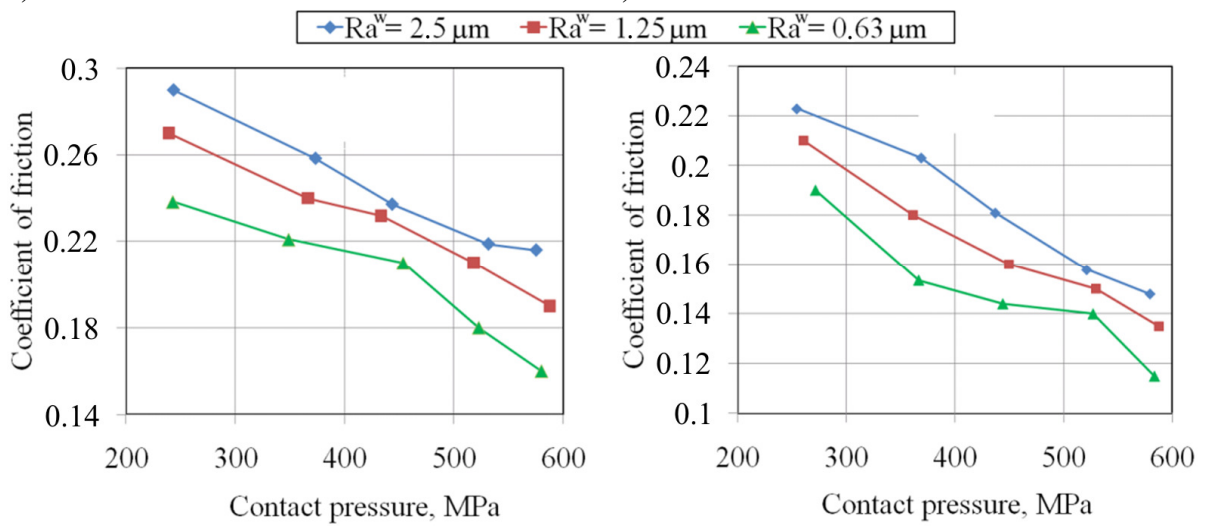

Fig. 2. Value of the friction coefficient versus value of contact pressure in dry (a) and oil (b) conditions

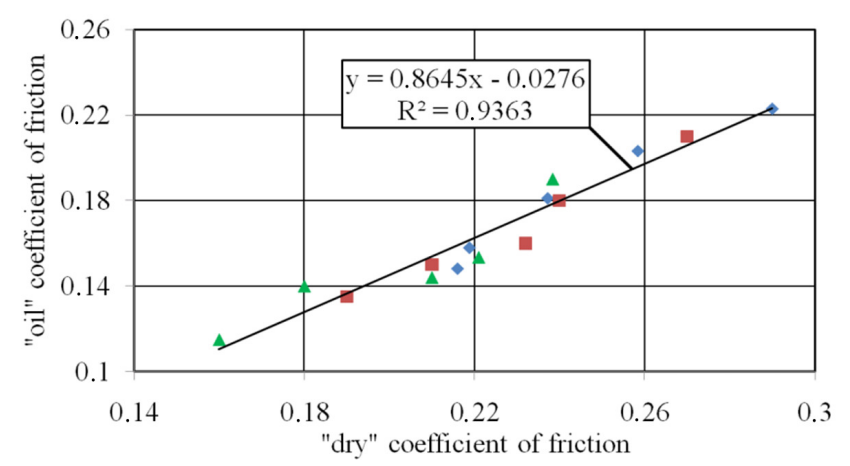

Fig. 3. Value of the friction coefficient determined in dry friction conditions versus determined in oil conditions 
Table 2. Surface roughness parameters of the DDQ sheets after friction tests

\begin{tabular}{|c|c|c|c|c|c|c|c|c|}
\hline $\begin{array}{c}\boldsymbol{R a}^{\boldsymbol{w}} \text { of rollers } \\
{[\boldsymbol{\mu \mathrm { m } ]}]}\end{array}$ & $\begin{array}{c}\text { Friction } \\
\text { conditions }\end{array}$ & $\begin{array}{c}\boldsymbol{S a} \\
{[\boldsymbol{\mu} \mathrm{m}]}\end{array}$ & $\begin{array}{c}\boldsymbol{S} \boldsymbol{q} \\
{[\boldsymbol{\mu \mathrm { m } ]}]}\end{array}$ & $\begin{array}{c}\boldsymbol{S d q} \\
{[\boldsymbol{\mu \mathrm { m }} / \boldsymbol{\mu m}]}\end{array}$ & $\boldsymbol{S b i}$ & $\boldsymbol{S v i}$ & $\boldsymbol{S s k}$ & $\boldsymbol{S k u}$ \\
\hline \multirow{2}{*}{0.63} & oil & 1.29 & 1.56 & 0.085 & 0.814 & 0.092 & 0.0134 & 2.29 \\
\cline { 2 - 9 } & dry & 1.12 & 1.40 & 0.087 & 0.866 & 0.107 & -0.1981 & 2.38 \\
\hline \multirow{2}{*}{1.25} & oil & 1.59 & 1.94 & 0.081 & 0.420 & 0.104 & 0.0113 & 2.37 \\
\cline { 2 - 9 } & dry & 1.32 & 1.56 & 0.092 & 0.403 & 0.095 & -0.1722 & 2.45 \\
\hline \multirow{2}{*}{2.5} & oil & 1.98 & 2.44 & 0.123 & 0.583 & 0.1 & -0.0025 & 2.39 \\
\cline { 2 - 9 } & dry & 1.89 & 3.32 & 0.112 & 0.439 & 0.097 & -0.0892 & 2.62 \\
\hline
\end{tabular}

For $R a$ of rollers equals to 0.63 and $1.25 \mu \mathrm{m}$ the friction process causes the decrease of value of amplitude parameters $S a$ and $S q$. For the highest roughness of rollers $R a=2.5 \mu \mathrm{m}$ the increase of amplitude parameters was observed. Lubrication in a lesser degree influences on decreasing of these parameters. It is connected with smoothing of sheet surface as a result of plastic squeezing of asperities of surface roughness. Furthermore, the suitable surface topography determines occurring oil pockets that influence on the decreasing of frictional resistance by producing oil cushion [15]. The oil pockets perform a role of oil reservoir and cause the decrease of the coefficient of friction. This leads to significant elimination of friction-welded connections and consequently decreasing of frictional resistance more than in dry friction conditions. The friction process accompanied decreasing of a value of both $S d q$ and $S v i$ parameters. For both friction conditions occurs the increase of initial value of $S b i$ parameter value. Topography of sheet before the friction tests has been shown in Fig. 4.

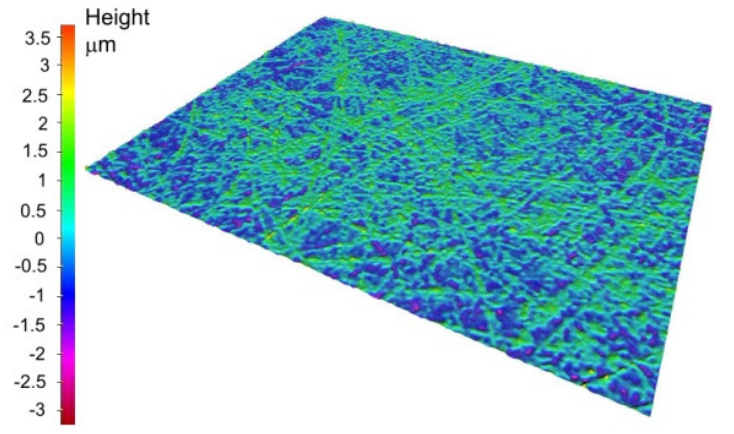

Fig. 4. Surface topography of DDQ sheet surface before friction test; area $1.4301 \times 1.0849 \mathrm{~mm}^{2}$

The shape of the contact area and surface roughness of contact bodies' influence on the type of the contact and stress state in the surface layer and also on the value of tangential force necessary to overcome the resistance to friction. Deformation occurs in the regions of contact spots, establishing stresses that oppose the applied load. The real area of the contact constitutes the sum of the 
areas of all contact spots. The real area of the contact is a function of the surface topography, material properties and loading conditions. For most contact metallic surfaces the real area of contact is a small fraction of the apparent area of the contact. The change of real area of the contact allows to ceaseless change of the contact area. As the total load increases the contacting surfaces bring closer together and the number of asperity contacts increases. The number of contact spots is roughly proportional to the load, and the fraction of the load carried by elastic contacts will not change - even though the original elastic contacts have become plastic. The estimation of surface roughness change is carried out for DDQ steel sheet. The tested samples were cut from the same fragment of the sheet. The friction tests were carried out for three arithmetic averages of rollers $R a^{w}$ (Table 3) in dry friction conditions.

Table 3. The results of sheet strip drawing test

\begin{tabular}{|c|c|c|}
\hline $\begin{array}{c}\text { Contact pressure } \\
{[\mathbf{M P a}]}\end{array}$ & $\begin{array}{c}\boldsymbol{R} \boldsymbol{a}^{\boldsymbol{w}} \\
{[\boldsymbol{\mu} \mathbf{m}]}\end{array}$ & $\begin{array}{c}\text { Friction } \\
\text { coefficient }\end{array}$ \\
\hline \multirow{3}{*}{240} & 0.63 & 0.231 \\
\cline { 2 - 3 } & 1.25 & 0.273 \\
\cline { 2 - 3 } & 2.5 & 0.291 \\
\hline \multirow{3}{*}{360} & 0.63 & 0.223 \\
\cline { 2 - 3 } & 1.25 & 0.262 \\
\cline { 2 - 3 } & 2.5 & 0.275 \\
\hline
\end{tabular}

The surface profiles of the sheets after friction tests carried out at normal pressures of rollers equals $240 \mathrm{MPa}$ and $360 \mathrm{MPa}$ they are presented in Figs. 5 and 6. In case of $R a^{w}=0.63 \mu \mathrm{m}$ the dominating phenomenon during friction process was smoothing of surface asperities. For both contact pressures of rollers the initial profile height was similar. The increase of arithmetic average $R a^{w}$ value causes ridging of the sheet surface. However, for contact pressure of rollers $360 \mathrm{MPa}$ during the increase of arithmetic average $R a^{w}$ from $1.25 \mu \mathrm{m}$ to 2.5 $\mu \mathrm{m}$ the increase of resistance to friction causing ringing process was not observed (Table 3). This may be explained by the fact that the increase of $R a^{w}$ complies with ridging process is balanced by decreasing of the real contact area.

The comparative analysis of surface profiles after friction testing with reference object has been performed by using Alicona InfiniteFocus optical 3D micro coordinate measurement system. The reference object was the original surface profile of the sheets before friction testing. It was assumed that the surface profile of the sheet before friction testing is representative for sheet surface.

The results of comparative analysis of sheet surface before and after friction tests are presented in Table 4. In all analyzed cases the friction process causes decreasing of surface roughness. In case of rollers with surface roughness $R a^{w}=0.63 \mu \mathrm{m}$ and $R a^{w}=1.25 \mu \mathrm{m}$ the largest volume roughness variation was 
above the reference surface (roughness smoothing). For rollers surface $R a^{w}=2.5$ $\mu \mathrm{m}$ the highest deviation of the tested surface in respect of the reference surface exists below the reference surface, which is caused by interaction of high surface roughness of rollers. The increase of $R a^{w}$ parameter value causes the increase of tool roughness penetration into the sheet surface. Consequently, the minimal and maximal deviation of the tested surface from the reference surface increased.

Many researches use standard 2D (3D) surface parameters $R a(S a), R q(S q)$ to describe the surface topography. In analysis of the influence of surface roughness parameters on the friction the $R s k$ and $R k u$ parameters provide a better knowledge about topography than $R a(S a)$ and $R q(S q)$ [16]. Parameter $R a(S a)$ does not describe contact surfaces entirely, since a completely different surface can have similar or even identical value of average surface roughness, and vice versa. The value of both $S s k$ and $S k u$ parameters after the friction tests carried out using all rollers becomes smaller (Fig. 7). The friction process under dry conditions causes the decrease of the value of Ssk parameter. In oil conditions decreasing of $S s k$ parameter value was lesser than in $d r y$ conditions. Friction processes carried out in both dry and oil conditions cause decreasing of kurthosis $S k u$ parameter, but in case of oil conditions the reduction of $S k u$ value is higher.

a)
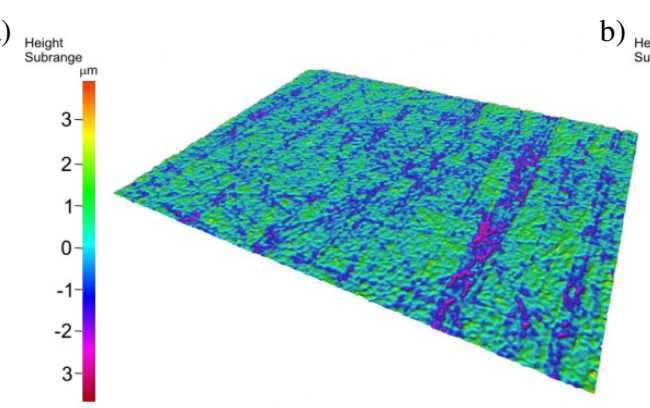

b)

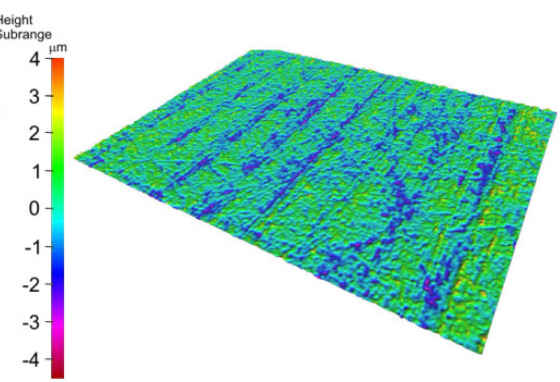

c)

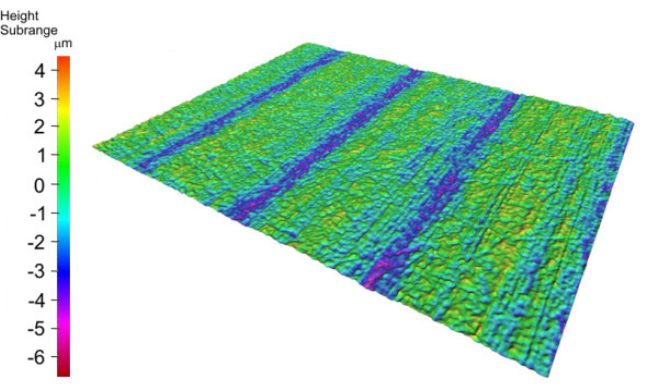

Fig. 5. Change of surface topography of DDQ steel sheet tested under rollers pressure equals $240 \mathrm{MPa}$ and for: a) $\left.R a^{w}=0.63 \mu \mathrm{m}, \mathrm{b}\right) R a^{w}=1.25 \mu \mathrm{m}$, c) $R a^{w}=2.5 \mu \mathrm{m}$ 

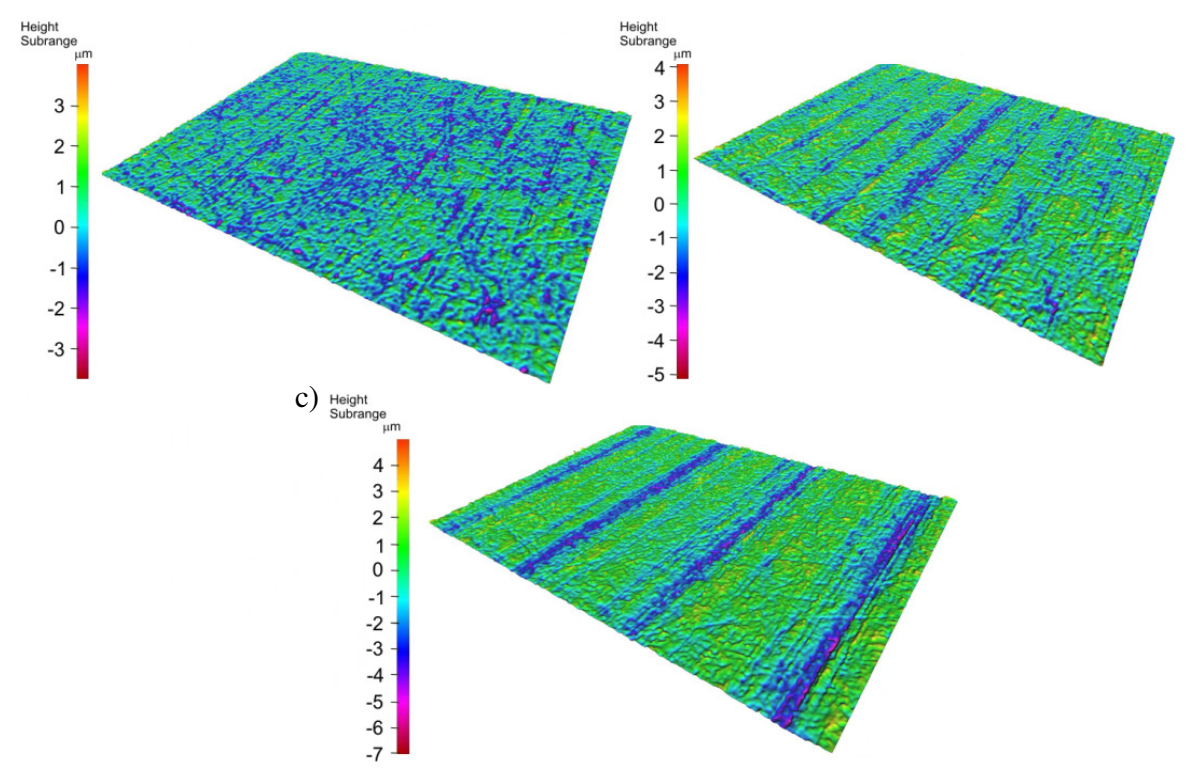

Fig. 6. Change of surface topography of DDQ steel sheet tested under rollers pressure equals $360 \mathrm{MPa}$ and for: a) $R a^{w}=0.63 \mu \mathrm{m}$, b) $R a^{w}=1.25 \mu \mathrm{m}$, c) $R a^{w}=2.5 \mu \mathrm{m}$

Table 4. Results of comparative analysis of surfaces before and after friction process

\begin{tabular}{|c|c|c|c|c|c|c|}
\hline \multirow[t]{2}{*}{$\begin{array}{c}\text { Contact } \\
\text { pressure } \\
\text { [MPa] }\end{array}$} & \multirow{2}{*}{$\begin{array}{c}R a \\
\text { of rolls } \\
R a^{w} \\
{[\mu \mathrm{m}]}\end{array}$} & \multicolumn{3}{|c|}{$\begin{array}{l}\text { Surface deviation after friction } \\
\text { process from reference surface } \\
\qquad[\mu \mathrm{m}]\end{array}$} & \multicolumn{2}{|c|}{$\begin{array}{c}\text { Volume change in relation } \\
\text { to reference surface } \\
{\left[{\left.\mu \mathrm{m}^{3}\right]}^{3}\right.}\end{array}$} \\
\hline & & $\min$ & $\max$ & mean & above & below \\
\hline \multirow{3}{*}{240} & 0.63 & -3.687 & 5.2309 & -0.0153 & 127783 & 113020 \\
\hline & 1.25 & -5.5176 & 4.009 & -0.0309 & 144368 & 121157 \\
\hline & 2.5 & -6.6996 & 4.4872 & -0.2787 & 153700 & 248358 \\
\hline \multirow{3}{*}{360} & 0.63 & -3.7411 & 5.4508 & -0.0064 & 129493 & 104458 \\
\hline & 1.25 & -5.122 & 4.0808 & -0.024 & 155633 & 135419 \\
\hline & 2.5 & -11.705 & 6.1676 & -0.3285 & 165294 & 240747 \\
\hline
\end{tabular}


a)

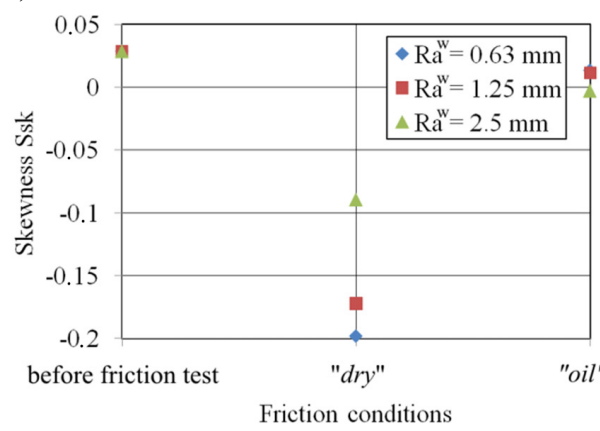

b)

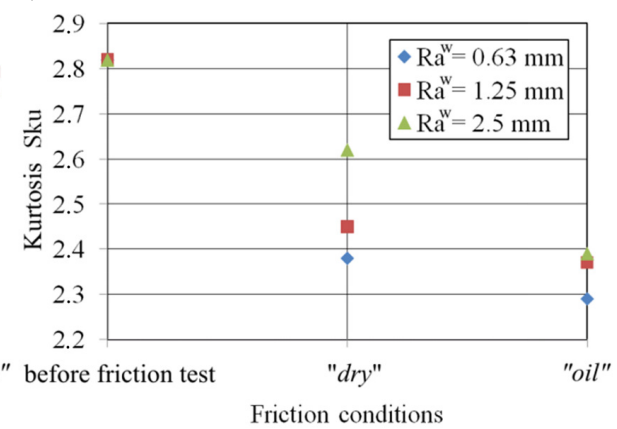

Fig. 7. Value of skewness $S s k$ (a) and kurtosis $S s k$ (b) parameters versus friction conditions for rollers $R a=0.63 \mu \mathrm{m}$

\section{Conclusions}

The article deals with problems related to analysis of the friction coefficient value determined in a strip-drawing test. The value of the friction coefficient decreases with increasing of the clamping force of rollers. It can be explained by nonlinear dependence between friction force and pressure force. Consequently the value of the coefficient of friction is not constant and changes with the increase of the pressure force. Achieved results may be summarized as follows. Variation of contact conditions determines the variation of surface topography of the sheet. For $R a$ of rollers equals to $0.63 \mu \mathrm{m}$ and $1.25 \mu \mathrm{m}$ friction process causes decreasing of the value of amplitude parameters $S a$ and $S q$. For the highest roughness of rollers $R a=2.5 \mu \mathrm{m}$ the increase of amplitude parameters was observed. The friction process accompanied decreasing of value of both $S d q$ and $S v i$ parameters. For both friction conditions occurs the increase of initial value of Sbi parameter value. Analysis of surface topography of tested sheets for different rollers visibly exhibits directionality of geometrical structure of surface. The value of both $S s k$ and $S k u$ parameters after the friction tests carried out using all rollers becomes smaller. The friction process under oil conditions causes smaller decrease of value of $S s k$ parameter than for dry friction conditions. In oil conditions the decrease of $S k u$ parameter value was greater than in $d r y$ friction conditions.

\section{References}

[1] Totten G.E.: Handbook of lubrication and tribology. Vol. I: Application and maintenance, 2nd ed. CRC Press, New York 2006.

[2] Firat M., Cicek O.: A FE technique to improve the accuracy of drawbead models and verification with channel drawing experiments of a high-strength steel. Int. J. Adv. Manuf. Technol., 55 (2011), 107-119. 
[3] Evin E., Tomáš M., Semjon V.: Study of Fe-Zn coated steel sheets tribological characteristics. Tribologia, 44 (2013), 35-46.

[4] Evin E., Kollárová M.: Tribologické vlastnosti pozinkovaných plecov pre karosérie áut. Chem. Listy, 105 (2011), 465-467.

[5] Stachowicz F., Trzepieciński T.: ANN application for determination of frictional characteristics of brass sheet metal. J. Artif. Intell., 2 (2004), 81-90.

[6] Kowalik M., Trzepieciński T.: Experimental and numerical study of friction in sheet metal forming processes. Adv. Sci. Lett., 19 (2013), 338-341.

[7] Trzepieciński T., Lemu H.G.: Application of genetic algorithms to optimize neural networks for selected tribological tests. J. Mech. Eng. Autom., 2 (2012), 69-76.

[8] Trzepieciński T.: Analysis of the friction influence on the change of surface topography in strip drawing test. Tribologia, 44 (2013), 125-134.

[9] Weinmann K.J., Bhonsle S.R., Gerstenberger J.: On the determination of the coefficient of friction and the friction factor by the strip-tension friction test. CIRP Ann. - Manuf. Technol., 39 (1990), 263-266.

[10] Hortig D., Schmoeckel D.: Analysis of local loads on the draw die profile with regard to wear using the FEM and experimental investigations. J. Mat. Proc. Technol., 115 (2001), 153-158.

[11] Choudhury I.A., Lai O.H., Wong L.T.: PAM-STAMP in the simulation of stamping process of an automobile component. Simul. Model. Pract. Theory, 14 (2006), 71-81.

[12] Costa H.L., Hutchings I.M.: Effects of die surface patterning on lubrication in strip drawing. J. Mat. Proc. Technol., 209 (2009), 1175-1180.

[13] Kowalewski P.: Numeryczna analiza rozkładów nacisku występujących w standardowych węzłach tribologicznych. Tribologia, 41 (2010), 39-47.

[14] Czupryk W., Krawiec M.: Wpływ nacisku i prędkości poślizgu na opory tarcia przy smarowaniu smarami plastycznymi w procesie tłoczenia blach. Tribologia, 39 (2008), 127-135.

[15] Wihlborg A., Crafoord R.: Steel sheet surface topography and its influence on friction in a bending under tension friction test. Int. J. Mach. Tools Manuf., 41 (2001), 1953-1959.

[16] Sedlaček M., Vilhena L.M.S., Podgornik B., Vižintin J.: Surface topography modelling for reduced friction. Stroj. Vestn. - J. Mech. Eng., 57 (2011), 674-680.

\section{WPEYW WARUNKÓW TARCIA NA ZMIANE CHROPOWATOŚCI POWIERZCHNI BLACH PODCZAS TLOCZENIA}

\section{Streszczenie}

$\mathrm{W}$ pracy przedstawiono zagadnienia związane $\mathrm{z}$ analizą tarcia występującego podczas kształtowania blach. Aby określić wpływ wartości parametrów chropowatości blach oraz wałków, a także wartości nacisków na wartość współczynnika tarcia, przeprowadzono testy przeciągania paska blachy. Ponadto przeprowadzono analizę wpływu warunków tarcia na zmianę parametrów chropowatości blach. Analizę topograficzną badanych próbek wykonano za pomocą systemu pomiarowego Alicona InfiniteFocus. Testowanym materiałem były niskowęglowe głębokotłoczne 
blachy stalowe. W przypadku rolek o parametrze chropowatości $R a=0,63 \mu \mathrm{m} \mathrm{i} 1,25 \mu \mathrm{m}$ zaobserwowano wygładzanie wierzchołków nierówności blachy podczas procesu tarcia. Dla rolki o chropowatości $R a=2,5 \mu \mathrm{m}$ największe odchylenie powierzchni poddanej tarciu względem powierzchni referencyjnej wystąpiło poniżej tej powierzchni. W analizowanych warunkach tarcia obserwowano zmniejszenie wartości parametrów chropowatości powierzchni Ssk i Sku, które są podstawowymi parametrami charakteryzującymi topografię powierzchni blach używanych do tłoczenia. Podczas badań prowadzonych w warunkach tarcia suchego wartość parametru chropowatości $S s k$ była mniejsza niż podczas tarcia w warunkach smarowania, dla parametru $S k u$ zależność jest odwrotna.

Słowa kluczowe: współczynnik tarcia, tarcie, kształtowanie blach

DOI:10.7862/rm.2013.33

Otrzymano/received: $15.04 .2013 \mathrm{r}$.

Zaakceptowano/accepted: 12.08.2013 r. 